\author{
Marquette University \\ e-Publications@Marquette
}

College of Nursing Faculty Research and

Publications

Nursing, College of

$5-1-2007$

\title{
The Influence of Religiosity on Contraceptive Use among Roman Catholic Women in the United States
}

Jennifer Ohlendorf

Marquette University

Richard J. Fehring

Marquette University, richard.fehring@marquette.edu

Follow this and additional works at: https://epublications.marquette.edu/nursing_fac

Part of the Maternal, Child Health and Neonatal Nursing Commons

\section{Recommended Citation}

Ohlendorf, Jennifer and Fehring, Richard J., "The Influence of Religiosity on Contraceptive Use among Roman Catholic Women in the United States" (2007). College of Nursing Faculty Research and

Publications. 2.

https://epublications.marquette.edu/nursing_fac/2 


\title{
The Influence of Religiosity on Contraceptive Use among Roman Catholic Women in the United States
}

by

\author{
Jennifer Ohlendorf, M.S., R.N. and Richard J. Fehring, Ph.D., R.N.
}

Ms. Ohlendorf is Clinical Instructor, Marquette University College of Nursing. There also, Dr. Fehring is Professor and Director, Marquette University College of Nursing Institute for Natural Family Planning

\section{Introduction}

The National Survey of Family Growth (NSFG) has been conducted by the National Center for Health Statistics, a department of the Department of Health and Human Services (DHHS), approximately every 3-7 years since 1973 to describe contraceptive use among United States (US) women. The DHHS uses the collected data and subsequent reports published from that data to plan programs and set policy related to reproductive health. The NSFG data is made available to researchers, who analyze it to determine trends in family size and makeup, contraceptive choices, and contraceptive effectiveness.

The NSFG is conducted using a nationally representative, randomly selected sample of women aged 15-44 in the US. Interviews are conducted in person and take approximately 80 minutes to complete. In the 2002 NSFG (Cycle 6) there were 7,635 women in the sample, 2,250 of whom were Catholic (29.5\%). ${ }^{1}$ In 2002, the 3 most frequent methods of contraception among all US women (in order of frequency) were oral hormonal contraception (i.e., the birth control pill), male sterilization, and condoms. Only 15 women between the ages of $15-44$ (or $0.2 \%$ of the sample) listed natural family planning (NFP) as their current method of family planning.

In 1995 there were 7,780 women in the NSFG (Cycle 5) sample, and $3,130(40.2 \%)$ of those were Roman Catholic (RC). ${ }^{2}$ An analysis of the 1995 data revealed that the most common methods of family planning 
among RC women were oral hormonal contraception, male sterilization, and the condom. These 3 most common methods of contraception were the same 3 as the national sample as a whole. One surprising statistic in the 1995 data is the dramatic increase since the 1973 survey in the use of sterilization (male or female) among married couples. The rate almost doubles from $23.1 \%$ to $41.1 \%$. $^{3}$ No one, as yet, has analyzed or published the 2002 NSFG data specific to the sub-sample of RC couples.

Since the RC Church teaches that artificial means of contraception are morally unacceptable and that the only morally acceptable means of spacing pregnancies is NFP, one would expect contraceptive practices of Catholic women to be different from those of all other US women. Another expectation would be that RC teachings influence the choice and methods of family planning of Catholic women. A separate analysis of the contraceptive use by US Catholic women and the influence of the RC faith will provide an opportunity to compare and contrast that data with the general population of US women. This information will be useful to Church leaders as they set priorities for Church teaching and program planning and to Catholic health care professionals and health care systems that provide NFP services. Furthermore, this information could be helpful to NFP teachers in targeting their NFP services to those most likely to be interested.

Conceptually, we hypothesized that Catholic women who believe that their religion is very important and who frequently attend Church services would have reported a higher use of NFP and lower use of other contraceptive methods, in particular sterilization, oral hormonal contraception (i.e., the pill), and the condom. We also hypothesized that Catholic women who hold to basic tenets of their faith in regards to human sexuality (i.e., those who are orthodox with Catholic sexual ethics) would also have reported a higher use of NFP and less frequent use of sterilization, the pill, and condoms. The overall purpose of this research was to determine the relationship of religiosity and contraceptive use among RC women in the US. Our specific research questions were: 1) What are the contraceptive practices of US Catholic women?, 2) How do the contraceptive practices of US Catholic women compare to all other US women?, 3) Do importance of religious belief, frequency of church attendance, and orthodox belief influence contraceptive use among US Catholic women?

\section{Method}

There were 7,365 women participants in the 2002 Cycle 6 of the NSFG and 3,456 variables in the data set. The authors analyzed the variables related to current and "ever use" of contraceptive methods and 
NFP, religiosity, and separately analyzed the data of the 2,250 Catholic female respondents. We analyzed the survey items that most closely represented the concept of religiosity so that we could determine whether the strength of one's belief in the Catholic religion and orthodoxy to RC teachings on human sexuality, made a difference in women's contraceptive practices.

Two variables from the NSFG data set were used to measure religiosity among the RC sample: 1) "How often respondent (R) attends religious services," and 2) "How important religion is in R's daily life." For the attendance question respondents could choose 1 of 5 items for a response: 1) More than once a week, 2) Once a week, 3) 1-3 times per month, 4) Less than once a month, and 5) Never. For analysis purposes the responses were collapsed into 2 categories: 1) Frequent Church Attendance $=$ more than once a week, once a week, and 1-3 times per month and 2) Not Frequent Church Attendance $=$ less than once a month and never.

Importance of religion in R's daily life was originally reported as: 1) Very important, 2) Somewhat important, and 3) Not important. For analysis purposes these responses were dichotomized into 2 categories: 1 ) Very Important, and 2) Not Important.

Orthodoxy with the Roman Catholic faith was measured by an "agree" or "strongly agree" response to 3 items from the NSFG: 1) "Same sex relationships between two adults is always wrong", 2)"Not OK for a young couple to live together unless married," and 3) "Rewards of being a parent are worth it despite the cost." The "agree" or "strongly agree" responses were categorized as " 1 " and the "disagree" or "strongly disagree" responses as " 2 " for statistical purposes.

Descriptive statistics were used to determine demographic makeup of the general US and RC sample and to determine frequency of contraceptive use with the 3 most utilized methods and with NFP. Relative risk odds ratios (OR) i.e., likelihood to use a method of contraception (based on $95 \%$ confident intervals) were calculated with the RC sample dichotomized by: 1) frequent church attendance versus not frequent attendance, 2) religion is important versus not important, and 3) orthodox versus non-orthodox views on RC sexual teachings. The comparison dependent variables were oral hormonal pill use, female sterilization, male sterilization (vasectomy), condom use, and NFP use. Statistical significance was set at the 0.05 probability level. Statistical analysis was performed by use of the Statistical Package for Social Sciences (SPSS version 15).

The NSFG Cycle 6 data set is available through the National Center for Health Statistics either through the mail or downloadable into SPSS files. The data set does not contain any identifying variables and is intended for public use. 


\section{Results}

There were 7,635 US women and 2,250 US Catholic women who answered the questions about contraceptive practices and whose data were included in this analysis (See Table 1, below). The mean age of the US women was $29.50(\mathrm{SD}=8.43)$, and the mean age of the US RC women was $29.44(\mathrm{SD}=8.35)$. The mean parity for US women was 1.22 living children, while the mean parity for US RC women was 1.29 living children. A slightly higher percentage of US RC women were married $(43.0 \%)$ compared to US women in general (39.1\%).

Table 1: Demographics of all women respondents (and the Roman Catholic subset) in Cycle 6 of the Natural Survey of Family Growth.

\begin{tabular}{|c|c|c|}
\hline & $\begin{array}{c}\text { U.S. Women } \\
\text { Mean \& SD }\end{array}$ & $\begin{array}{c}\text { U.S. Catholic Women } \\
\text { Mean \& SD }\end{array}$ \\
\hline Age & $29.50(8.43)$ & $29.44(8.35)$ \\
\hline Parity & $1.22(1.39)$ & $1.29(1.38)$ \\
\hline Married & $39.1 \%$ & $43.0 \%$ \\
\hline Cohabit & $9.1 \%$ & $10.8 \%$ \\
\hline Divorced & $11.3 \%$ & $10.0 \%$ \\
\hline Single & $40.0 \%$ & $35.4 \%$ \\
\hline
\end{tabular}

The frequency and percentages of "ever use" of contraceptive methods and NFP among US women and US RC women can be found in Table 2 (below).

Table 2: Frequency (and percentage) of contraceptive method used in month of interview among US and Roman Catholic women in the 2002 NSFG

\begin{tabular}{|c|c|c|}
\hline Method & $\begin{array}{c}\text { U.S. Women } \\
\mathrm{N}=7,635\end{array}$ & $\begin{array}{c}\text { U.S. Catholic Women } \\
\qquad=2,250\end{array}$ \\
\hline Birth Control Pill & $1448(18.9 \%)$ & $442(19.6 \%)$ \\
\hline Female Sterilization & $1148(15.0 \%)$ & $312(13.9 \%)$ \\
\hline Male Sterilization & $324(04.2 \%)$ & $80(03.6 \%)$ \\
\hline Condom & $977(12.8 \%)$ & $264(11.7 \%)$ \\
\hline NFP & $15(00.2 \%)$ & $10(00.4 \%)$ \\
\hline
\end{tabular}

When compared to US women in general, RC women were slightly more likely to be currently using the birth control pill (18.9\% of US/19.6\% of US Catholic) and NFP ( $0.2 \%$ of US/ $0.4 \%$ of US Catholic), were less likely 
to use surgical sterilization (male and female combined) (19.2\% of US/ $17.5 \%$ of US Catholic), and were equally likely to be using condoms (12.8\% of US/11.7\% of US Catholic).

The OR of using a method of contraception (the birth control pill, sterilization, or condoms) and NFP among US RC women based on frequency of attendance at religious services, importance of religion, and orthodoxy in RC sexual teachings can be found in Table 3 (next page).

\section{Church Attendance}

When compared to those with low church attendance, women with high church attendance were $38 \%$ more likely to be sterilized $(\mathrm{OR}=1.381$, $\mathrm{CI}=1.092-1.745)$ and $51 \%$ more likely to have a male partner who was sterilized (vasectomy) $(\mathrm{OR}=1.505 ; \mathrm{CI}=1.084-2.096)$. Those women with high church attendance were also $48 \%$ less likely ever to have used condoms $(\mathrm{OR}=0.519 ; \mathrm{CI}=0.403-0.670)$ compared to low church attendance women, but there was no difference in frequency in ever use of the birth control pill. However, women with high church attendance were $188 \%$ more likely ever to have used NFP compared to low attendance women.

\section{Importance of Religion}

When compared to those who reported religion as not very important, those women who reported religion as very important were $68 \%$ more likely to be sterilized $(\mathrm{OR}=1.689, \mathrm{CI}=1.337-2.135)$, but there is no statistical difference in frequency of having a male partner who has been sterilized. However, those women who view religion as very important, were $21 \%$ less likely ever to have used the pill $(\mathrm{OR}=0.792$; CI $=0.663-0.947)$ and $50 \%$ less likely ever to have used the male condom $(0.501 ; \mathrm{CI}=0.390-0.644)$ than women who reported religion as not very important. Those women who reported religion as very important were $164 \%$ more likely ever to have used NFP.

\section{Orthodox Sexual Ethics}

Those women who were orthodox to RC sexual ethics were $26 \%$ less likely ever to have used the pill $(\mathrm{OR}=0.737$; $\mathrm{CI}=0.542-1.003)$ and $91 \%$ more likely ever to have used NFP than women who were less orthodox with RC teachings on sexual ethics. There were no statistically significant differences in frequency of "ever use" of female and male sterilization and condom use between orthodox and non-orthodox RC women. 
Table 3: Odds ratios of using a method of family planning among Catholic women based on church attendance, importance of religion, and orthodoxy in sexual teachings.

\begin{tabular}{|c|c|c|c|}
\hline \multicolumn{4}{|c|}{ Frequency of Church Attendance: RC women with high attendance } \\
\hline $\begin{array}{c}\text { Method of Family } \\
\text { Planning }\end{array}$ & Odds Ratio & $\begin{array}{l}95 \% \text { Confident } \\
\text { Interval }\end{array}$ & Significance \\
\hline Use of Pill & 0.877 & $0.734-1.049$ & 0.150 \\
\hline Female Sterilization & 1.381 & $1.092-1.745$ & 0.007 \\
\hline Male Sterilization & 1.507 & $1.084-2.096$ & 0.014 \\
\hline Condom Use & 0.519 & $0.403-0.670$ & 0.000 \\
\hline NFP Use & 2.878 & $1.819-4.533$ & 0.000 \\
\hline \multicolumn{4}{|c|}{ Importance of Religion: $\mathrm{RC}$ women who view religion as very important } \\
\hline $\begin{array}{l}\text { Method of Family } \\
\text { Planning }\end{array}$ & Odds Ratio & $\begin{array}{c}95 \% \text { Confident } \\
\text { Interval }\end{array}$ & Significance \\
\hline Use of Pill & 0.792 & $0.663-0.947$ & 0.010 \\
\hline Female Sterilization & 1.689 & $1.337-2.135$ & 0.000 \\
\hline Male Sterilization & 1.355 & $0.967-1.844$ & 0.078 \\
\hline Condom Use & 0.501 & $0.390-0.644$ & 0.000 \\
\hline NFP Use & 2.636 & $1.701-4.085$ & 0.000 \\
\hline \multicolumn{4}{|c|}{ Orthodox Sexual Ethics: RC women who are orthodox with sexual ethics } \\
\hline $\begin{array}{c}\text { Method of Family } \\
\text { Planning }\end{array}$ & Odds Ratio & $\begin{array}{c}95 \% \text { Confident } \\
\text { Interval }\end{array}$ & Significance \\
\hline Use of Pill & 0.737 & $0.542-1.003$ & 0.052 \\
\hline Female Sterilization & 0.868 & $0.564-1.355$ & 0.519 \\
\hline Male Sterilization & 1.007 & $0.577-1.819$ & 0.983 \\
\hline Condom Use & 0.734 & $0.486-1.110$ & 0.141 \\
\hline NFP Use & 1.906 & $1.058-3.433$ & 0.029 \\
\hline
\end{tabular}

\section{Discussion}

The overall findings from the 2002 NSFG indicate that US RC women between the ages of 15-44 have patterns of use of contraceptive methods similar to those of US women in general. The current use of contraceptive methods by US women and US RC women differ only by a percentage point. The 3 most frequently used methods of family planning by both US women and RC US women are the hormonal oral contraceptive pill, sterilization, and the condom. However, of note is the fact that most of the women who use modern methods of NFP (mucus and temperature) are RC. When the 15 users of NFP in the data set are extrapolated to the total number of women in the US, about 124,000 currently use NFP as their primary method of family planning. 
The findings also show that RC women were more likely (90-187\%) to have used NFP if they attend church services frequently, believe that their RC faith is very important, and are orthodox in their sexual ethics. Furthermore, RC women with frequent church attendance and who view their faith as very important were approximately 50\% less likely ever to have used condoms than women with lower attendance and who do not view their faith as very important. $\mathrm{RC}$ women who view their religion as very important and who hold orthodox sexual ethics had less frequent "ever use" of the pill. What is startling in these findings, however, is that $\mathrm{RC}$ women who have frequent church attendance and who view their religion as very important had more frequent (38-69\%) "ever use" of female sterilization.

The infrequent use of NFP by RC women is not surprising. The use of NFP among RC couples has been declining since the 1950s when there was a high frequency of use among married RC couples of about $54 \% .4,5$ The use of NFP has declined and leveled off to around 2-3\% among married couples since $1988 .{ }^{6}$ The use of sterilization in contrast has been increasing among married $\mathrm{RC}$ couples and had a large increase in use from $20 \%$ to approximately $39 \%$ between 1988 and 1995 . The sharp increase in rates of sterilization might reflect the aging of the large baby boom generation, the completion of the baby boom generation's family size, and the decline of female fertility as women of the baby boom generation have reached their 50s and 60s. Women in this age range no longer wish to be using hormonal contraception and are probably tired of managing their fertility. Women are also often confused by their irregular cycles and are fearful of an unwanted pregnancy in this stage of their life.

One reason that "faithful" RC women - those who frequent church and believe that their religion is very important - had more frequent use of sterilization (than less-faithful Catholics) is that sterilization is a one-time event. Couples can have the sterilization surgery, confess to a priest, and then be back in the grace of God and the Church. The constant use of the pill and/or condoms, on the other hand, requires either frequent confession or a guilty conscience. This sterilization and one-time forgiveness process was first speculated by Professor Leslie Woodcock Tentler (from Catholic University of America) in her book Catholics and Contraception; An American History. ${ }^{7}$

Another reason for the use of sterilization among "faithful" Catholic couples might be a lack of understanding of the Church's teaching on family planning and sexual ethics. This second reason is somewhat supported by the findings showing that the subset of women with orthodox sexual ethics did not have a higher frequency of male (partner) or female sterilization. In fact, the trend in the use of sterilization among this group of orthodox women (with greater statistical power) might have shown a 
less likely odds ratio in sterilization. Another possible reason is that, although RC couples know the Church's teachings on contraception and sterilization, they view themselves as "autonomous" adults, and downplay or ignore the role of the Church's official teachings in forming their consciences on the issue of family planning. ${ }^{7}$

Although the NSFG data is probably the best and largest data set on contraceptive use among a representative sample of women in the US, there are limits to this study and to the data set. The NSFG data set focused on all women between the ages of 15-44, not only married women. Approximately $27 \%$ of the US and US RC respondents were not using any method of family planning in the month of interview (i.e., the most frequent method was no method of contraception). Some of these women were not sexually active, some were trying to achieve a pregnancy, and some were currently pregnant. Another limit was the difficulties of trying to measure religiosity among $\mathrm{RC}$ women using a retrospective data set. Religiosity has multiple dimensions that include belief, intrinsic religiosity, religious well-being, and participation in organized religious activity. ${ }^{8}$ The measure of religiosity in this study was limited to the items used in the 2002 NSFG. A very important component of religiosity that is missing is whether the RC faith is intrinsic (or extrinsic) to the individual respondent.

Recommendations for future research include comparing the findings from the 2002 NSFG data set with the data from the 1995 (Cycle 5) data set. The 1995 NSFG had a greater number of US women $(10,847)$ and $\mathrm{RC}$ women respondents (over 3,000). Comparing results would help to determine trends in contraceptive use and religiosity. A unique and new feature of the 2002 NSFG is the inclusion of 4,928 randomly selected male respondents. Therefore, another analysis that could be made would be to compare the answers from the male respondents to the answers from the female respondents in the 2002 NSFG, using the same variables. Another important area would be to analyze the influence of religiosity on important cultural groups, particularly the Hispanic US RCs. A final recommendation would be to conduct studies on $\mathrm{RC}$ populations that measure the influence of an intrinsic religiosity on contraceptive use.

Although there seems to be some influence of religion on the family planning choices of $\mathrm{RC}$ women, it is still quite apparent that $\mathrm{RC}$ women and couples have difficulty in either living with or accepting their fertility. This is evident from the fact that their most frequent ways of dealing with fertility are to suppress it with the hormonal pill, block it with condoms, or destroy it with surgery. Another implication is that although women and couples view their faith as very important, they may not have a good understanding of the faith and what it teaches, especially in the area of sexuality and contraception. This is further exacerbated by the lack of support from clergy and Catholic health professionals and Catholic health 
institutions in the area of family planning. Relatively few physicians, advanced practice nurses, and Catholic health facilities offer and promote the use of NFP. ${ }^{8-12}$

Perhaps the most important finding from this analysis of this large data set is that there is a mixed influence of religion on women's contraceptive practices. It is encouraging that there is a higher use of NFP in women who attend church services frequently and in those who report religion as very important. However, there is also a frequent use of surgical sterilization among this same group. This would seem to indicate a need for better catechesis, perhaps at a younger age, for Catholic men and women. However, further research would be helpful in determining whether religious beliefs enter into the decision of women who are choosing a method of family planning at all. Perhaps more discussion of God's true design for marriage, the Theology of the Body, and strategies for living with one's fertility would lead more women to reconsider their contraceptive practices and to encourage a newfound interest in living with fertility in accordance with God's plan.

\section{References:}

1. Mosher, W.D., "Use of Contraception and Use of Family Planning Services in the United States: 1982-2002," Adv Data, 2004;10 (350):1-36.

2. Piccinino, L.J., Mosher, W.E., "Trends in Contraceptive Use in the United States: 1982-1995," Family Planning Perspectives, 1998;30 (1):4-10,46.

3. Fehring R. Schlidt, A.M., "Trends in Contraceptive Use Among Catholics in the United States: 1988-1995," The Linacre Quarterly, 69;2001;(2):170-185.

4. Westoff, C.F., Ryder, N.R., "Conception Control among American Catholics," Chapter in, (Liu, W.T. \& Pallone, N.J. Editors) Catholics/U.S.A.; Perspectives on Social Change. New York; John Wiley \& Sons: 257-268, (1970).

5. Bachrach, C., "Contraceptive Practice among American Women, 1973-1982," Family Planning Perspectives, 1984;16:253-260.

6. Mosher, W.D., "Contraceptive Practice in the United States, 1982-1988," Family Planning Perspectives, 1990;22(5):198-205.

7. Tentler, L.W., Catholics and Contraception: An American History. Ithaca, New York: Cornell University Press, 2004. 
8. Koenig, H.G., Smiley, M., Gonzales J.A.P., Religion, Health, and Aging. A Review and Theoretical Integration. Westport, Connecticut: Greewood Press, 1988.

9. Fehring R., "Physician and Nurses' Knowledge and Use of Natural Family Planning," The Linacre Quarterly, 1995;62, 22-8.

10. Fehring, R., Hanson, L, Stanford, J., "Nurse-Midwives' Knowledge and Promotion of Lactational Amenorrhea and Other Natural Family Planning Methods for Child Spacing," Journal of Midwifery \& Women's Health, 2001;46(2), 68-73.

11. Stanford, J.B., Thurman, P.B., Lemaire, J.S., "Physicians' Knowledge and Practice Regarding Natural Family Planning." Obstetrics and Gynecology, 1999;94, 672-678.

12. Fehring, R., Werner, C., "Natural Family Planning and Catholic Hospitals: A National Survey," The Linacre Quarterly, 1993;60(4), 29-34. 